\title{
Utilization of Sunnhemp Meal in Beef Cattle Diet Supplemented with Urea-Treated Rice Straw
}

\author{
Supreena Srisaikham $^{1^{*}}$ and Pipat Lounglawan ${ }^{2 *}$
}

${ }^{1}$ Faculty of Agricultural Technology, Burapha University, Sa Kaeo Campus, Sa Kaeo 27160, Thailand

${ }^{2}$ School of Animal Technology and Innovation, Institute of Agricultural Technology, Suranaree University of Technology, Nakhon Ratchasima 30000 Thailand

"Corresponding authors. E-mail: supreena.sr@buu.ac.th, pipat@sut.ac.th https://doi.org/10.12982/CMUJNS.2020.0055

Received: December 4, 2019

Revised: February 15, 2020

Accepted: March 12, 2020

\begin{abstract}
The objective of this study was to determine the effects of the utilization of sunnhemp (Crotalaria juncea) meal (SM) in beef cattle diet in North-East Thailand. The first experiment was conducted to determine the effects of cutting intervals and height on the yield and nutrient composition of sunnhemp. The experiment was a $3 \times 3$ factorial arrangement in a randomized complete block design ( $R C B D$ ), in which factor $A$ was the cutting intervals (30, 40 and 50 days) and factor $B$ was the cutting heights $(30,40$ and $50 \mathrm{~cm})$ above ground level. It is concluded that a cutting interval of sunnhemp at 50 days achieves greater dry matter and nutrient yields than at 30 days. In terms of nutrient content, there is also a considerable increase in crude fiber, neutral-detergent fiber, acid-detergent fiber, and acid-detergent lignin in sunnhemp. In contrast, the results showed that cutting height at 30, 40 or 50 cm had no effect on the chemical composition values of sunnhemp. The second experiment was to study the effect of SM supplemented with ureatreated rice straw (UTRS) on the growth rate of Brahman $\times$ Thai-Native beef cattle. Twelve cattle, averaging $218 \pm 14 \mathrm{~kg}$ body weight $(B W)$ and approximately 14-17 months' old were stratified randomly and assigned to RCBD in 4 treatments of 3 beef cattle each. The treatments were equal amounts of SM supplement with UTRS at 0, 25, 50 and $75 \%$ respectively. There were no significant differences in the live weight change, average daily gain (ADG), dry matter intake and rumen fermentation among treatments of
\end{abstract}




\section{0, 25 and 50\% of SM supplement. However, the BW and ADG significantly decreased at $75 \%$ of SM supplement with UTRS.}

Keywords: Crotalaria juncea, Sunnhemp meal, Beef cattle diet, Urea-treated rice straw

\section{INTRODUCTION}

Livestock feed is an important factor in the success of cattle farming. Animal feed costs are usually accounts for $60-70 \%$ of animal production (Habtamu, 2014), of which approximately 10 up to $16 \%$ are roughage and 65$80 \%$ are concentrated feed expenses (Wanapat et al., 2013), depending on the quality of the feed and the feeding method (Seyoum et al., 2007). Supplementing the concentrate from a basal feed diet or grass fortifies nutritional deficiencies. However, fresh grass is only of good quality at an early stage, because the nutritive value of fresh grass may vary throughout the year and its quality gradually decreases with the age of forage harvest and rising temperature (Lee et al., 2017). Therefore, it is necessary to supplement it with high levels of concentrated feed in order for the cattle to receive sufficient nutrients for production, which causes higher production costs for farmers. Concentrated feed consists of 2 types of important nutrients, which are, firstly, a basal diet, such as diets with high carbohydrates which are usually low in price and, secondly, protein supplements. Cattle are usually fed a concentrated diet, which means that they do not often get enough protein to meet their nutrient requirements, especially in steer cattle. The provision of protein supplements mixed with basic feed will increase the protein content for animals. Most protein supplements are derived from the oil extracted or expressed from types of grain, such as palm kernel meal, cotton seed meal (Wanapat and Rowlinson, 2007) and soybean meal (Martens et al. , 2012), etc. , Although these protein sources are of good quality, more palatable and contain different amounts of protein according to the type of plant, they are expensive. The problem is how to decrease the expensive price of the protein feed for beef cattle to supplement poor quality roughage in order to achieve efficient production. This can be done by adding protein supplements from other plant sources which provide the energy of the basal diet plus the added nutritive value from the feed intake.

Many legume species have the potential to be used as the raw material for animal feed, and widely grown especially in the tropics and subtropical areas of India, Nepal, Srilanka and Southern Africa ( Tripathi et al., 2013). Sunnhemp ( Crotalaria juncea) is a type of legume plant grown for fiber ( Tripathi et al., 2012) that has been mostly used as a green manure ( Sarkar and Ghoroi, 2007; Tripathi et al., 2013) to improve soil fertility by nitrogen fixation (Rhizobium), medicinal values (Lawal et al., 2013), local fodder (Sarkar et al., 2015) and is 
more suitable for use in cattle feed than grasses (Fraser et al., 2004) due to its high protein content (Srisaikham and Lounglawan, 2018). However, we have not been able to find any studies on this in Thailand.

Thai farmers allow a rest period for cultivation which encourages plants to grow, especially sunnhemp, which can be used as cover cropping to improve soil properties, reduce soil erosion, conserve soil water, and recycle plant nutrients (USDA, 1999). However, planting and plowing are generally less useful, although they provide other benefits as sunnhemp can be used as fodder, which may possibly be another way to solve the main problem of feed shortage for ruminant animals by producing a lower cost diet per ton. In addition, sunnhemp leaves can be used in a dried form as the raw materials for animal diet or as a supplement for a poultry diet (USDA, 1999) or African catfish diet (Lawal et al., 2013). Therefore, this study aimed to investigate the utilization of sunnhemp meal (SM) partially supplemented with urea-treated rice straw (UTRS) to investigate the effects on feed intake, growth performance, nutrient digestibility and ruminal fermentation in beef cattle.

\section{MATERIAL AND METHODS}

\section{Effects of cutting heights and cutting intervals on the yield and nutrient composition of sunnhemp}

The present study formed part of a larger research trial that evaluated the effects of cutting intervals and height on the yield and nutrient composition of sunnhemp, as reported previously (Sumalu et al., 2012), and observed their utilization of SM on the production of BrahmanxThai-Native beef cattle. The experiment was conducted in a $3 \times 3$ Factorial in a Randomized Complete Block Design (RCBD), in which factor A was the cutting intervals (30, 40 and 50 days of age) and factor $B$ was the cutting heights $(30,40$ and $50 \mathrm{~cm})$ with 4 replications giving a total of 36 plots each $(3 \times 3 \mathrm{~m})$ at Suranaree University' $\mathrm{s}$ Farm. The experimental site located on the GPS co-ordinates of Suranaree University of Technology, Nakhon Ratchasima province, Thailand at $14^{\circ} 52^{\prime}$ $13.49^{\prime \prime} \mathrm{N}$ latitude and $102^{\circ} 01^{\prime} 15.19^{\prime \prime} \mathrm{E}$ longitude, where the average annual extreme maximum and minimum temperature, total amount of rainfall, number of rainy days and daily maximum ranges between 13.7 to $40.1{ }^{\circ} \mathrm{C}, 1,179.5$ millimeter, 113.5 day and 104.5 millimeter (Meteorological Department, Ministry of Information and Communication Technology, 2015). The sunnhemp seeds were obtained from the Land Development Station in Nakhon Ratchasima province, Thailand. The soil of the field crops in Suranaree district, Nakhon Ratchasima province was classified in a group of Korat soil series (Korat series: $\mathrm{Kt}$ ) which have low fertility and are composed of sandy loam. The soil was prepared for planting by plowing in regular furrows twice followed by 1 more 
tillage subsequently so that the soil was ready for planting. The plot used for planting was $1 \mathrm{~m}^{2}$ and each plot was divided into 6 rows. The planting space between rows and plants was $50 \times 50 \mathrm{~cm} .15 \mathrm{~N}-15 \mathrm{P}-15 \mathrm{~K}$ chemical fertilizer was used on the soil surface after plowing at the rate of $187.5 \mathrm{~kg}$ per ha with a planting rate of $12.5 \mathrm{~kg}$ seeds per ha and irrigation by the drip system. The total amount of fresh sunnhemp harvested from the whole plot yielded a fresh weight of $500 \mathrm{~g}$ of sunnhemp. Samples of the harvest were randomly collected from each plot to determine plant height, chemical composition and dry weight per plant.

\section{Feeding of animals and the experimental design}

All the procedures involving animals in this study were performed in accordance with the guidelines and ethics standards of the National Requirements of Beef Cattle in Thailand as specified by the working committee of Thai Feeding Standards for ruminants (WTSR) (2008) for the care and use of animals. Twelve Brahman $\times$ Thai-Native cattle were divided by BW into 4 treatments of 3 cattle each which were housed in individual pens and their body weight (BW) averaged $218 \pm 14 \mathrm{~kg}$ and they were approximately 14-17 months old. They were then assigned to the RCBD. All the cattle were fed $1 \%$ of their BW or approximately $3 \mathrm{~kg} / \mathrm{d}$ of $14 \% \mathrm{CP}$ concentrate with supplements of 0,25 , 50 and $75 \%$ of sunnhemp meal (SM) which were used as roughage to substitute for the urea-treated rice straw (UTRS) which was provided twice daily. The treatments were: 1) concentrate and $0 \%$ of SM supplement dry matter (DM; the proportion of plant dry mass to fresh mass) (w/ w) together with ad libitum UTRS; 2) concentrate and $25 \%$ of SM supplement DM (w/w) together with ad libitum UTRS; 3 ) concentrate and 50\% of SM supplement DM (w/w) together with ad libitum UTRS; and 4) concentrate and 75\% of SM supplement DM $(\mathrm{w} / \mathrm{w})$ together with ad libitum UTRS. All cattle also had free access to clean water and they were individually housed in a free-stall unit and they were individually fed according to the treatments. The experiment lasted for 60 days with the first 2 periods $(14 \mathrm{~d})$ as an adjustment period. Urea-treated rice straw was prepared by using $5 \mathrm{~kg}$ urea of fertilizer grade $(46 \% \mathrm{~N})$ plus $100 \mathrm{~kg}$ water, sprayed onto $100 \mathrm{~kg}$ of the rice straw and then covered up for $10 \mathrm{~d}$ before directly before being fed to the animals (Wanapat et al., 2009). A detailed analysis of the dry matter of concentrate, roughage and total intake $(\mathrm{kg} / \mathrm{d})$ and the live weight of beef cattle fed 0,25,50 and 75\% of sunnhemp which was used as roughage to substitute for the urea treated rice straw has been reported previously (experiment 2; Lounglawan et al., 2016). 


\section{Measurements and chemical analysis}

Collection of the feed samples and rumen fluid for chemical analysis. The feed left after the individual cattle had eaten were collected after a $10 \mathrm{~d}$ period and dried at $60{ }^{\circ} \mathrm{C}$ for $48 \mathrm{~h}$. At the end of the experiment, feed samples were pooled to make representative samples for proximate and detergent analyses which were repeated three times. Samples were ground through a 1 $\mathrm{mm}$ screen and analyzed for dry matter (DM), and then heated in a hot air oven at $60{ }^{\circ} \mathrm{C}$ for $48 \mathrm{~h}$. An analysis of the crude protein (CP, Kjeldahl analysis) (AOAC, 1990) and of the ether extract (EE, petroleum ether in a Soxtec System) was then conducted. Fiber fraction, neutral detergent fiber (NDF) and acid detergent fiber (ADF) were determined using the method described by Van Soest et al. (1991), adapted for a Fiber Analyzer. Ash content was determined by ashing in a muffle furnace at $600{ }^{\circ} \mathrm{C}$ for $3 \mathrm{~h}$. The chemical analysis was expressed based on the final DM. Cattle were weighed at the start and at the end of the experiment after a fasting period of at least $16 \mathrm{~h}$ to calculate the average daily gain (ADG) and the feed intake per BW. Approximately $60 \mathrm{ml}$ of ruminal fluid were collected by using a stomach tube with a strainer and a vacuum pump.

The rumen fluid was immediately used for determining the $\mathrm{pH}$ using a digital pH meter (MP 220 pH Meter, Mettler-Toledo Gombh, CH-9603 Schwerzenbach, Switzerland). The sample was then filtrated through a clean double layer of cheesecloth at 0 and $4 \mathrm{~h}$ post morning feeding on 2 consecutive days of the experimental period. The liquid fraction of rumen fluid was divided into two parts, where one part at approximately $20 \mathrm{ml}$ was immediately fixed with $6 \mathrm{~N} \mathrm{HCl}$ and approximately $5 \mathrm{ml}$ were then centrifuged for $15 \mathrm{~min}$ at 3,000 $\times \mathrm{g}$. Approximately $15 \mathrm{ml}$ of supernatant of the rumen fluid were kept at $-20{ }^{\circ} \mathrm{C}$ for analysis of ammonia-nitrogen $\left(\mathrm{NH}_{3}-\mathrm{N}\right)$ concentration by distillation according to the Kjeldahl method (AOAC, 1990). The second part from the liquid fraction was acidified with $1 \mathrm{M} \mathrm{H}_{2} \mathrm{SO}_{4}(9: 1 \mathrm{w} / \mathrm{w})$, centrifuged at 5,000 x g for 15 minutes and stored at $-20{ }^{\circ} \mathrm{C}$ for analysis of volatile fatty acids (VFAs) including of acetic acid $\left(\mathrm{C}_{2}\right)$, propionic acid $\left(\mathrm{C}_{3}\right)$ and butyric acid $\left(\mathrm{C}_{4}\right)$. The supernatant of the rumen fluid was analyzed for concentrations of VFAs which were determined by gas chromatography (GC) (Hewlett Packard GC system HP6890 A; Hewlett Packard, Avondale, PA) equipped with a $30 \mathrm{~m} \times 0.32 \mathrm{~mm}$ $\times 0.15 \mu \mathrm{m}$ film silica capillary column (HP_Innowax, AB 002, Agient, USA). Injector and detector temperatures were $250{ }^{\circ} \mathrm{C}$. The column temperature was kept at $80{ }^{\circ} \mathrm{C}$ for $5 \mathrm{~min}$, then increased from $10{ }^{\circ} \mathrm{C} / \mathrm{min}$ to $170{ }^{\circ} \mathrm{C}$ and then increased again from $30{ }^{\circ} \mathrm{C} / \mathrm{min}$ to $250{ }^{\circ} \mathrm{C}$ and held at $250{ }^{\circ} \mathrm{C}$ for $5 \mathrm{~min}$.

\section{Statistical analysis}

Measured data of chemical composition and yields ( $\mathrm{kg} / \mathrm{ha}$ ) of sunnhemp cut at different ages and heights were analyzed by ANOVA for a 3x3 Factorial 
in $\mathrm{RCBD}$, whereas the feed intake, $\mathrm{BW}$ change, nutrient digestibility, rumen$\mathrm{pH}, \mathrm{NH}_{3}-\mathrm{N}$ and VFAs of the cattle were analyzed by ANOVA for RCBD using the Statistical Analysis System (SAS, 2001). Significant differences among treatments were assessed by Duncan' $\mathrm{s}$ new multiple range test (DMRT). A significant level of $P<0.05$ was used (Steel and Torries, 1980).

\section{RESULTS}

\section{Effects of cutting intervals (30, 40 and $50 \mathrm{~d})$ and cutting height $(30,40$ and $50 \mathrm{~cm}$ ) on the chemical composition of sunnhemp}

There was an interactional effect between the cutting intervals and the nutrient content of sunnhemp for DM, CF, NDF ADF and ADL, which increased as the cutting intervals increased from 30, 40 and 50 days respectively, while the $\mathrm{CP}$, ash, $\mathrm{EE}$ and NFE showed decreases as the cutting intervals increased. In addition, the results of cutting at different heights $(30,40$ and $50 \mathrm{~cm})$ as shown in Table 1 showed significant differences $(P<0.05)$ on $\mathrm{CP}, \mathrm{EE}$ and ADF. In this case, the mean of CP and EE increased with increased cutting height and, on the other hand, the mean ADF decreased.

Table 1. Chemical composition (\%) of sunnhemp (Crotalaria juncea) cut at different intervals (ages) and heights. (Mean)

\begin{tabular}{|c|c|c|c|c|c|c|c|c|c|c|}
\hline $\begin{array}{c}\text { Age } \\
\text { (days) }\end{array}$ & Height & $\begin{array}{c}\mathbf{D M}^{2} \\
(\%)\end{array}$ & $\begin{array}{l}\mathbf{C P}^{3} \\
(\%)\end{array}$ & $\begin{array}{l}\mathrm{EE}^{4} \\
(\%)\end{array}$ & $\begin{array}{c}\text { ASH } \\
(\%)\end{array}$ & $\begin{array}{l}C^{5} \\
(\%)\end{array}$ & $\begin{array}{c}\mathrm{NFE}^{6} \\
(\%)\end{array}$ & $\begin{array}{c}\mathrm{NDF}^{7} \\
(\%)\end{array}$ & $\begin{array}{c}\mathbf{A D F}^{\mathbf{8}} \\
(\%)\end{array}$ & $\begin{array}{c}\text { ADL }^{9} \\
(\%)\end{array}$ \\
\hline \multirow[t]{3}{*}{30} & $30 \mathrm{~cm}$ & 20.31 & 22.21 & 3.07 & 7.66 & 12.37 & 34.17 & 26.36 & 24.37 & 4.31 \\
\hline & $40 \mathrm{~cm}$ & 18.89 & 23.31 & 3.42 & 7.97 & 12.34 & 34.54 & 26.54 & 24.45 & 3.68 \\
\hline & $50 \mathrm{~cm}$ & 19.72 & 25.69 & 3.16 & 7.39 & 12.23 & 32.02 & 24.80 & 21.25 & 3.13 \\
\hline \multirow[t]{3}{*}{40} & $30 \mathrm{~cm}$ & 23.84 & 20.12 & 2.71 & 6.47 & 18.84 & 27.89 & 39.32 & 33.03 & 6.53 \\
\hline & $40 \mathrm{~cm}$ & 23.67 & 20.23 & 2.66 & 6.73 & 18.53 & 28.60 & 40.75 & 31.64 & 5.56 \\
\hline & $50 \mathrm{~cm}$ & 23.64 & 21.32 & 2.96 & 6.86 & 17.29 & 28.10 & 37.24 & 31.36 & 4.83 \\
\hline \multirow[t]{3}{*}{50} & $30 \mathrm{~cm}$ & 23.49 & 18.82 & 2.26 & 6.37 & 25.76 & 23.74 & 54.33 & 47.19 & 8.84 \\
\hline & $40 \mathrm{~cm}$ & 23.38 & 20.29 & 2.65 & 6.49 & 22.98 & 24.98 & 44.80 & 45.36 & 8.52 \\
\hline & $50 \mathrm{~cm}$ & 23.15 & 19.81 & 2.62 & 6.52 & 23.17 & 23.90 & 50.72 & 43.95 & 8.37 \\
\hline SEM $^{1}$ & & 0.45 & 0.14 & 0.05 & 0.07 & 0.50 & 0.50 & 1.03 & 0.72 & 0.35 \\
\hline Block & & 0.0001 & 0.0001 & 0.0001 & 0.0001 & 0.0001 & 0.0001 & 0.0001 & 0.0001 & 0.0001 \\
\hline Age & & 0.0001 & 0.0001 & 0.0001 & 0.0001 & 0.0001 & 0.0001 & 0.0001 & 0.0001 & 0.0001 \\
\hline Height & & 0.373 & 0.0001 & 0.0007 & 0.0711 & 0.8993 & 0.1094 & 0.0994 & 0.0306 & 0.0650 \\
\hline Agexheight & & 0.5727 & 0.0001 & 0.0123 & 0.0402 & 0.2976 & 0.4346 & 0.0227 & 0.6507 & 0.8184 \\
\hline
\end{tabular}

Note: ${ }^{1} \mathrm{SEM}=$ standard error of mean ${ }^{2} \mathrm{DM}=\operatorname{dry}$ matter; ${ }^{3} \mathrm{CP}=$ Crude protein; ${ }^{4} \mathrm{EE}=$ Ether extract; ${ }^{5} \mathrm{CF}=$ Crude fiber, ${ }^{6} \mathrm{NFE}=$ Nitrogen Free Extract; ${ }^{7} \mathrm{NDF}=$ Neutral detergent fiber; ${ }^{8} \mathrm{ADF}=$ Acid detergent fiber;

${ }^{9} \mathrm{ADL}=$ Acid detergent lignin. 


\section{Effects of cutting intervals and cutting height on the yield of sunnhemp}

The DM yields at different cutting intervals and heights of sunnhemp between harvests are presented in Table 2. Different cutting intervals and heights of sunnhemp harvests resulted in changes in the dry matter yield of sunnhemp, which were characterized by increases the cutting periods from $2,482 \mathrm{~kg}$ per ha at 30 days to $13,644 \mathrm{~kg}$ per ha at 50 days, and increases in the maximum growth rate of sunnhemp at 50 days as shown in Table 2 . The growth rate was higher than the cutting intervals of 30 and 40 days. In terms of the chemical composition, the production per ha showed that the DM, CP, EE, ash, $\mathrm{CF}$, NFE, NDF, ADF and ADL increased significantly $(P<0$. 05) with increasing cutting intervals. In addition, when the cutting height increased from 30,40 and $50 \mathrm{~cm}$, this resulted in decreases in the CF, NDF, ADF and ADL, with no significant differences for DM, CP, EE, ash and NFE. However, there was a marked interactional effect of cutting intervals and height on CF content yield only.

Table 2. Yields (kg/ ha) of sunnhemp (Crotalaria juncea) cut at different intervals (ages) and heights

\begin{tabular}{|c|c|c|c|c|c|c|c|c|c|c|}
\hline Age (days) & Height & $\mathbf{D M}^{2}$ & $\mathbf{C P}^{3}$ & $\mathrm{EE}^{4}$ & ASH & $\mathrm{CF}^{5}$ & $\mathrm{NFE}^{6}$ & $\mathbf{N D F}^{7}$ & $\mathbf{A D F}^{8}$ & ADL $^{9}$ \\
\hline \multirow[t]{3}{*}{30} & $30 \mathrm{~cm}$ & 947 & 214 & 30 & 85 & 139 & 380 & 293 & 271 & 48 \\
\hline & $40 \mathrm{~cm}$ & 917 & 213 & 32 & 76 & 120 & 328 & 254 & 234 & 36 \\
\hline & $50 \mathrm{~cm}$ & 619 & 159 & 19 & 43 & 72 & 187 & 145 & 124 & 13 \\
\hline \multirow[t]{3}{*}{40} & $30 \mathrm{~cm}$ & 2778 & 559 & 80 & 197 & 573 & 854 & 1199 & 1005 & 196 \\
\hline & $40 \mathrm{~cm}$ & 2594 & 525 & 72 & 183 & 503 & 778 & 1101 & 863 & 150 \\
\hline & $50 \mathrm{~cm}$ & 2378 & 507 & 77 & 172 & 430 & 706 & 937 & 785 & 121 \\
\hline \multirow[t]{3}{*}{50} & $30 \mathrm{~cm}$ & 5056 & 949 & 137 & 386 & 1555 & 1433 & 3302 & 2846 & 534 \\
\hline & $40 \mathrm{~cm}$ & 4139 & 841 & 95 & 233 & 824 & 897 & 1602 & 1624 & 305 \\
\hline & $50 \mathrm{~cm}$ & 4450 & 880 & 133 & 335 & 1187 & 1230 & 2594 & 2258 & 431 \\
\hline $\mathrm{SEM}^{1}$ & & 436 & 87 & 7 & 24 & 73 & 89 & 179 & 140 & 27 \\
\hline Block & & 0.0001 & 0.0001 & 0.0001 & 0.0007 & 0.0001 & 0.0009 & 0.0001 & 0.0001 & 0.0001 \\
\hline Age & & 0.0001 & 0.0001 & 0.0001 & 0.0001 & 0.0001 & 0.0001 & 0.0001 & 0.0001 & 0.0001 \\
\hline Height & & 0.4290 & 0.7010 & 0.2582 & 0.1601 & 0.0269 & 0.1275 & 0.0457 & 0.0472 & 0.0315 \\
\hline Age $\times$ height & & 0.8688 & 0.9770 & 0.0804 & 0.2275 & 0.0445 & 0.2876 & 0.0504 & 0.0902 & 0.1095 \\
\hline
\end{tabular}

Note: ${ }^{1} \mathrm{SEM}=$ standard error of mean ${ }^{2} \mathrm{DM}=$ dry matter; ${ }^{3} \mathrm{CP}=$ Crude protein; ${ }^{4} \mathrm{EE}=$ Ether extract; ${ }^{5} \mathrm{CF}=$ Crude fiber, ${ }^{6} \mathrm{NFE}=$ Nitrogen-Free Extract $;{ }^{7} \mathrm{NDF}=$ Neutral-detergent fiber; ${ }^{8} \mathrm{ADF}=$ Aciddetergent fiber; ${ }^{9} \mathrm{ADL}=$ Acid-detergent lignin. 


\section{Chemical composition of feed}

The nutritive value of the concentrated diet $(14 \% \mathrm{CP}), \mathrm{SM}$ and UTRS is indicated in the present study (Table 3) for reference which was reported previously (Lounglawan et al., 2016). The SM was used as the main raw material in the beef cattle diet supplemented with UTRS of which the mean value of DM, CP, EE, ash, CF, NDF, ADF was approximately 90. 62, 19. 61, $2.43,6.01,26.80,53.04,47.34$ and $8.75 \%$ of ADL, respectively, while NDF $(75.5 \%)$ was the main component in UTRS.

Table 3. Chemical composition (\% DM) of the concentrate and roughage $\left(\right.$ Mean $\left.\pm \mathrm{SE}^{1}\right)$ used in the study $(\mathrm{n}=2)$

\begin{tabular}{|c|c|c|c|}
\hline Item & Concentrate & Sunnhemp meal & Urea-treated rice straw \\
\hline \multicolumn{4}{|c|}{ - } \\
\hline $\mathrm{DM}^{2}$ & $90.04 \pm 0.12$ & $90.62 \pm 0.69$ & $66.14 \pm 0.30$ \\
\hline $\mathrm{CP}^{3}$ & $14.62 \pm 1.99$ & $19.61 \pm 0.65$ & $7.77 \pm 0.10$ \\
\hline $\mathrm{EE}^{4}$ & $3.43 \pm 0.08$ & $2.43 \pm 0.32$ & $0.66 \pm 0.64$ \\
\hline Ash & $5.45 \pm 0.57$ & $6.01 \pm 1.06$ & $4.29 \pm 0.14$ \\
\hline $\mathrm{CF}^{5}$ & $12.48 \pm 1.05$ & $26.80 \pm 2.39$ & $35.80 \pm 0.14$ \\
\hline $\mathrm{NDF}^{6}$ & $31.67 \pm 1.78$ & $53.04 \pm 0.30$ & $75.50 \pm 0.14$ \\
\hline $\mathrm{ADF}^{7}$ & $18.57 \pm 0.48$ & $47.34 \pm 0.12$ & $51.40 \pm 0.18$ \\
\hline $\mathrm{ADL}^{8}$ & $5.27 \pm 0.53$ & $8.75 \pm 0.12$ & $11.18 \pm 0.94$ \\
\hline
\end{tabular}

\section{Nutrient intake and live weight}

The DM intake of roughage decreased with increases in the SM supplement with UTRS as shown in Table 4. Considering the DM intake per BW per day $(\% \mathrm{BW})$ and the metabolic weight per day $\left(\mathrm{g} / \mathrm{kgBW}^{0.75}\right)$ neither the concentrated diet, roughage or total intake were significantly different $(P>$ $0.05)$. The mean values of DM intake $(\% \mathrm{BW})$ and $\left(\mathrm{g} / \mathrm{kgBW}^{0.75}\right)$ in the concentrated diet were $1.09 \% \mathrm{BW} / \mathrm{d}$ and $43.2 \mathrm{~g} / \mathrm{kgBW}^{0.75} / \mathrm{d}, 2.28 \% \mathrm{BW} / \mathrm{d}$ and $90.7 \mathrm{~g} / \mathrm{kgBW}^{0.75} / \mathrm{d}$ in roughage and $3.36 \% \mathrm{BW} / \mathrm{d}$ and $134 \mathrm{~g} / \mathrm{kgBW}^{0.75} / \mathrm{d}$ in total intake, respectively. The live weight change (LWC) and ADG of beef cattle that resulted from SM supplemented with UTRS at $25 \%$ was higher than that of the cattle which received 50 and $75 \%$ (Table 4). The results from before and after SM was supplemented with UTRS at 25, 50 and $75 \%$ in ADG showed that the maximum response was observed at the lowest level as the LWC and ADG of 
cattle decreased when SM was supplemented with increases of UTRS from 542 $\mathrm{g}$ per day to 423 and $345 \mathrm{~g}$ per day, respectively. However, the average weight at the end of the experiment showed that no remarkable changes were found in the final weights among the treatments $(P>0.05)$.

Table 4. Effect of sunnhemp meal supplemented with urea-treated rice straw on nutrient intake and growth performance of BrahmanxThai-Native cattle.

\begin{tabular}{|c|c|c|c|c|c|c|}
\hline \multirow{2}{*}{ Item } & \multicolumn{4}{|c|}{ Sunnhemp meal level } & \multirow[t]{2}{*}{ SEM $^{1}$} & \multirow[t]{2}{*}{$\begin{array}{c}P \\
\text { value }\end{array}$} \\
\hline & $\mathbf{0 \%}$ & $25 \%$ & $50 \%$ & $75 \%$ & & \\
\hline \multicolumn{7}{|l|}{ Concentrate } \\
\hline Dry matter intake, $\mathrm{kg}^{2} / \mathrm{d}^{3}$ & 2.70 & 2.70 & 2.70 & 2.70 & - & - \\
\hline$\% \mathrm{BW}^{4}$ & 1.06 & 1.08 & 1.09 & 1.12 & 0.05 & 0.67 \\
\hline $\mathrm{g}^{5} / \mathrm{kgBW}^{0.75}$ & 42.4 & 42.9 & 43.5 & 44.0 & 0.83 & 0.28 \\
\hline \multicolumn{7}{|l|}{ Roughage } \\
\hline Dry matter intake, $\mathrm{kg} / \mathrm{d}$ & $6.09^{\mathrm{a}}$ & $5.81^{\mathrm{a}}$ & $5.40^{\mathrm{ab}}$ & $5.31^{\mathrm{b}}$ & 0.16 & 0.05 \\
\hline$\% \mathrm{BW}$ & 2.39 & 2.32 & 2.22 & 2.19 & 0.11 & 0.67 \\
\hline $\mathrm{g} / \mathrm{kgBW}^{0.75}$ & 95.7 & 92.41 & 88.3 & 86.5 & 4.56 & 0.24 \\
\hline \multicolumn{7}{|l|}{ Total } \\
\hline Dry matter of total intake, $\mathrm{kg} / \mathrm{d}$ & $8.79^{\mathrm{a}}$ & $8.51^{\mathrm{a}}$ & $8.31^{\mathrm{ab}}$ & $8.01^{b}$ & 0.15 & 0.04 \\
\hline$\% \mathrm{BW}$ & 3.45 & 3.40 & 3.31 & 3.31 & 0.19 & 0.25 \\
\hline $\mathrm{g} / \mathrm{kgBW}^{0.75}$ & 138.1 & 135.3 & 131.8 & 130.5 & 3.09 & 0.12 \\
\hline \multicolumn{7}{|l|}{ Live weight change } \\
\hline Initial live weight, $\mathrm{kg}$ & 225.4 & 217.6 & 221.1 & 219.2 & 3.2 & 0.72 \\
\hline Final live weight, $\mathrm{kg}$ & 254.7 & 250.1 & 246.5 & 239.9 & 4.8 & 0.13 \\
\hline Live weight change, $\mathrm{g} / \mathrm{d}$ & $29.3^{\mathrm{ab}}$ & $32.5^{\mathrm{a}}$ & $25.4^{\mathrm{bc}}$ & $20.7^{\mathrm{c}}$ & 3.1 & 0.05 \\
\hline Average daily gain, g/d & $488^{\mathrm{ab}}$ & $542^{\mathrm{a}}$ & $423^{\mathrm{bc}}$ & $345^{\mathrm{c}}$ & 41.2 & 0.04 \\
\hline
\end{tabular}

Note: In each row, different superscripts represent significant differences $(P<0.05),{ }^{1} \mathrm{SEM}=$ standard error of mean, ${ }^{2} \mathrm{~kg}=$ kilogram; ${ }^{3} \mathrm{~d}=$ day; ${ }^{4} \mathrm{BW}=$ body weight $;{ }^{5} \mathrm{~g}=$ gram.

\section{Nutrient digestibility}

The supplemented diets of SM with UTRS in beef cattle had no effect on $\mathrm{DM}, \mathrm{CP}, \mathrm{EE}, \mathrm{CF}, \mathrm{NDF}, \mathrm{ADF}$ and ADL digestibility, the total digestible nutrients, digestibility energy (DE) or metabolisable energy (ME) in all the treatments (Table 5). 
Table 5. Effect of sunnhemp meal supplemented with urea-treated rice straw on nutrient digestibility of Brahman×Thai-Native cattle.

\begin{tabular}{|c|c|c|c|c|c|c|}
\hline \multirow[t]{2}{*}{ Item } & \multicolumn{4}{|c|}{ Sunnhemp meal level } & \multirow[t]{2}{*}{ SEM $^{1}$} & \multirow[t]{2}{*}{$P$ value } \\
\hline & 0\% & $25 \%$ & $\mathbf{5 0 \%}$ & $75 \%$ & & \\
\hline $\mathrm{DM}^{2}$ & 62.76 & 61.77 & 59.87 & 60.71 & 1.17 & 0.26 \\
\hline $\mathrm{CP}^{3}$ & 60.72 & 59.47 & 63.96 & 61.96 & 2.31 & 0.44 \\
\hline $\mathrm{EE}^{4}$ & 56.19 & 60.91 & 55.73 & 59.73 & 1.97 & 0.72 \\
\hline $\mathrm{CF}^{5}$ & 50.01 & 52.89 & 55.11 & 54.9 & 1.78 & 0.59 \\
\hline $\mathrm{NDF}^{6}$ & 45.19 & 42.99 & 40.55 & 41.42 & 1.95 & 0.29 \\
\hline $\mathrm{ADF}^{7}$ & 26.14 & 27.74 & 24.8 & 25.09 & 1.07 & 0.32 \\
\hline $\mathrm{TDN}^{8}(\%)$ & 65.56 & 62.56 & 63.09 & 64.8 & 0.99 & 0.47 \\
\hline $\mathrm{DE}^{9}(\mathrm{Mcal} / \mathrm{kgDM})$ & 3.02 & 2.92 & 2.98 & 2.95 & 0.08 & 0.35 \\
\hline $\mathrm{ME}^{10}(\mathrm{Mcal} / \mathrm{kgDM})$ & 2.48 & 2.43 & 2.45 & 2.45 & 0.09 & 0.29 \\
\hline
\end{tabular}

Note: ${ }^{1} \mathrm{SEM}=$ standard error of mean, ${ }^{2} \mathrm{DM}=$ dry matter; ${ }^{3} \mathrm{CP}=$ Crude protein; ${ }^{4} \mathrm{EE}=$ Ether extract; ${ }^{5} \mathrm{CF}=$ Crude fiber, ${ }^{6} \mathrm{NDF}=$ Neutral-detergent fiber; ${ }^{7} \mathrm{ADF}=$ Acid-detergent fiber; ${ }^{8} \mathrm{TDN}=$ Total digestible nutrients, TDN1X $(\%)=\operatorname{tdNFC}+\operatorname{tdCP}+(\operatorname{tdFA} \times 2.25)+\operatorname{tdNDF}-7(\mathrm{NRC}, 2001),{ }^{9} \mathrm{DE} 1 \mathrm{X}(\mathrm{Mcal} / \mathrm{kg})=$ $[(\operatorname{tdNFC} / 100) \times 4.2]+[(\operatorname{tdNDF} / 100) \times 4.2]+[(\mathrm{tdCP} / 100) \times 5.6]+[(\mathrm{FA} / 100) \times 9.4]-0.3$ Discount $=[(\mathrm{TDN} 1 \mathrm{X}$ $-[(0.18 \times \mathrm{TDN} 1 \mathrm{X})-10.3]) \times$ Intake $)] /$ TDN1X DEP $(\mathrm{Mcal} / \mathrm{kgDM})=$ DE1X $\mathrm{x}$ Discount ${ }^{10} \mathrm{MEp}=[1.01 \mathrm{x}$ $(\mathrm{DEp})-0.45]+[0.0046 \times(\mathrm{EE}-3)]$

\section{Rumen-pH, Ammonia Nitrogen ( $\left.\mathrm{NH}_{3}-\mathrm{N}\right)$ and Volatile Fatty Acid (VFA)}

Rumen-pH variables, $\mathrm{NH}_{3}-\mathrm{N}$ and rumen VFA in the concentrated diet of cattle in which SM was supplemented with UTRS at 0, 25, 50 and $75 \%$ were not significantly different $(P>0.05)$ among treatments at 0 and $4 \mathrm{~h}$ post feeding, and the mean $\mathrm{pH}$ values of rumen fluid were 6.86, 6.91, 6.83 and 6.89, respectively (Table 6). These values of ruminal $\mathrm{pH}$ were maintained above 5.5 which is within the normal average range reported in the literature for ruminants. The values of $\mathrm{NH}_{3}-\mathrm{N}$ were 11.7, 12.88, 10.84 and $9.64 \mathrm{mg} \%$, respectively. SM supplemented with different amounts of UTRS at 0, 25, 50 and $75 \%$ had no effect on rumen VFA concentration (molar proportion of acetate $\left(\mathrm{C}_{2}\right)$, propionate $\left(\mathrm{C}_{3}\right)$, butyrate $\left(\mathrm{C}_{4}\right)$ and $\mathrm{C}_{2}: \mathrm{C}_{3}$ ratio) nor on rumen-pH and $\mathrm{NH}_{3}-\mathrm{N}$ (Table 6). 
Table 6. Effect of sunnhemp meal supplemented with urea-treated rice straw on rumen- $\mathrm{pH}$, ammonia nitrogen $(\mathrm{mg} / \mathrm{dl})$, individual and ratio of volatile fatty acid $(\mathrm{mol} / 100 \mathrm{~mol})$ at $0 \mathrm{~h}$ and after $4 \mathrm{~h}$ post feeding of Brahman $\times$ Thai-Native cattle.

\begin{tabular}{|c|c|c|c|c|c|c|}
\hline \multirow{2}{*}{ Item } & \multirow[b]{2}{*}{$0 \%$} & \multicolumn{3}{|c|}{ Sunnhemp meal level } & \multirow{2}{*}{ SEM $^{1}$} & \multirow{2}{*}{$P$ value } \\
\hline & & $25 \%$ & $50 \%$ & $75 \%$ & & \\
\hline \multicolumn{7}{|l|}{ pH } \\
\hline Hour 0 & 6.61 & 6.74 & 6.45 & 6.38 & 0.07 & 0.11 \\
\hline Hour 4 & 6.86 & 6.91 & 6.83 & 6.89 & 0.32 & 0.69 \\
\hline $\mathrm{NH}_{3} \mathrm{~N}^{2}$ & \multicolumn{4}{|c|}{$\left(\mathrm{mg} / \mathrm{dl}^{3}\right)$} & & \\
\hline Hour 0 & 7.01 & 8.58 & 7.57 & 7.27 & 0.28 & 0.34 \\
\hline Hour 4 & 11.71 & 12.88 & 10.84 & 9.64 & 0.20 & 0.10 \\
\hline Acetate; $\mathbf{C}_{2}$ & \multicolumn{4}{|c|}{$(\mathrm{mol} / 100 \mathrm{~mol})$} & & \\
\hline Hour 0 & 68.37 & 69.37 & 69.67 & 68.63 & 0.14 & 0.72 \\
\hline Hour 4 & 69.59 & 70.08 & 69.57 & 68.37 & 0.51 & 0.45 \\
\hline Propionate; $\mathrm{C}_{3}$ & \multicolumn{4}{|c|}{$(\mathrm{mol} / \mathbf{1 0 0} \mathrm{mol})$} & & \\
\hline Hour 0 & 20.75 & 20.91 & 20.25 & 21.03 & 0.47 & 0.43 \\
\hline Hour 4 & 20.58 & 20.43 & 20.27 & 20.37 & 0.53 & 0.39 \\
\hline Butyrate; $\mathrm{C}_{4}$ & \multicolumn{4}{|c|}{$(\mathrm{mol} / 100 \mathrm{~mol})$} & & \\
\hline Hour 0 & 10.88 & 9.71 & 9.90 & 10.31 & 0.31 & 0.31 \\
\hline Hour 4 & 10.53 & 9.97 & 10.20 & 11.09 & 0.23 & 0.92 \\
\hline \multicolumn{7}{|l|}{$\mathrm{C}_{2}: \mathrm{C}_{3}$} \\
\hline Hour 0 & 3.29 & 3.32 & 3.44 & 3.26 & 0.09 & 0.47 \\
\hline Hour 4 & 3.38 & 3.43 & 3.43 & 3.35 & 0.08 & 0.50 \\
\hline
\end{tabular}

\section{DISCUSSION}

Sunnhemp productivity increased with increased cutting intervals which was partly due to when the sunnhemp was planted and changes characterized by concomitant increases in the accumulation of nutrients from the soil. However, the differences in the yield of each crop in the research study suggested that several factors may have had an impact, for example, the sunnhemp may have been planted with different densities causing differences in growth. In addition, there are other factors that can affect the yield of the sunnhemp crop, such as soil integrity, harvesting, sunnhemp species and environmental conditions, etc. Therefore, soil type and particularly rainfall were the main factors which could 
not be controlled and these influenced the output of the sunnhemp in this experiment. Similar results were also reported in the research of Chantiratikul et al, (2006) which studied the yield and nutrient content of kenaf (Hibiscus cannabinus) at different growth stages of maturity. In a study in Tanzania (Mkiwa et al., 1990), which investigated the nutritive value and yield of Crotalaria ochroleuca, which is the same species as Crotalaria juncea, was harvested at different stages of growth, and it was found that the yield of the older cuttings had a greater effect on the amount of DM and organic matter (OM) which corresponds to Srisaikham et al. (2019) who reported that the average height, yiled (total weight per area), the fresh weight per plant and the DM per plant at $60{ }^{\circ} \mathrm{C}$ in a hot air oven in whole plants of legumes forage including alfalfa (Medicago sativa), Verano stylo (Hamata) (Stylosanthes hamata cv. Verano) and Tha pra stylo (Stylosanthes guianensis cv. Tha pra stylo) which belongs to the Fabaceae family similar to sunnhemp, and the 4 cutting ages were 30, 45, 60 and 75 days increased with increasing cutting ages.

Moreover, there was an interactional effect between the cutting intervals and the nutrient content of sunnhemp. Suksombat and Buakeeree, (2006) found that the leaf: stem ratio has an affect on the nutrients of plant. Levels of CP, EE, and ash decreased as the cutting interval increased, however, it tended to increase in the leaf as the cutting height increased but tended to decrease in the stem, while the NDF content increased with advancing plant maturity, especially in the stem fraction. Levels of $\mathrm{CP}$, EE, and ash were noticeably higher than the stem. The proportion of plant leaf was consistently higher than stem and all nutrients measured showed markedly higher contents in the leaf than in the stem. The various cutting intervals of Crotalaria ochroleuca affected the chemical composition including DM, CP, CF, EE, ash and NFE. A higher percentage of $\mathrm{CF}$ showed a significant response to increases in the cutting intervals whereas $\mathrm{CP}$, ash and $\mathrm{EE}$ decreased with increasing cutting intervals in Crotalaria ochroleuca for the whole plant, leaves and stems. Srisaikham and Rupitak ( 2019) reported that they found a significant interaction between type of legume forage (Alfalfa), Verano stylo (Hamata) and Tha pra stylo and cutting ages ( $30,45,60$ and 75 days) in all aspects of the chemical composition ( $P<$ 0.01) during the dry season on October 2018 to July 2019 in Sa Kaeo province. Each type of legume forage has an unequal response to increasing cutting ages. The chemical composition that decreased with increasing cutting ages were $\mathrm{DM}, \mathrm{CP}$, ash and tannin, whereas other chemical compositions (NDF, ADF and ADL) increased with increasing cutting ages. The average $\mathrm{CP}$ of 3 kinds of legumes decreased from $18.09 \%$ after the alfalfa was cut at 30 days from the first to fifth cutting intervals to $16.75 \%$ after cutting at 75 days, from $17.39 \%$ on the $30^{\text {th }}$ days of harvest to $14.77 \%$ on the $75^{\text {th }}$ days of harvest in Hamata and Tha pra stylo decreased from $18.02 \%$ to $12.97 \%$ on cutting at 30 days to 75 days respectively. This is in accordance with Srisaikham and Lounglawan (2018) who similarly demonstrated that CP of Crotalaria juncea decreased as 
the cutting interval increased from 35 to 55 days. The decrease in $\%$ ADF with increasing cutting height can possibly be attributed to the fact that the upper parts of the sunnhemp harvested at $50 \mathrm{~cm}$ height usually contained fewer branches and stems but more leaves than in the lower parts harvested at $30 \mathrm{~cm}$. Therefore, the cutting at a height of $50 \mathrm{~cm}$ leads to higher nutrient quality as reflected in the higher $\% \mathrm{CP}$ which is also in general agreement with the results of Srisaikham and Lounglawan (2018).

Although \% CP at greater cutting intervals decreased, the $\mathrm{CP}$ yield per cut of the sunnhemp significantly increased with increasing cutting intervals could consequent with the result that the dry weight of the crop increased rapidly especially during the intervals of 40 to 50 days. However, this study found a lower percentage of CP (19.8-25. 7\%) in sunnhemp when compared with a previous report of Chaudhury et al. (1995) who studied the chemical elements in various parts of Crotalaria juncea and reported that they found greater approximately $25-30 \% \mathrm{CP}$ in leaves which may have been the result of soil fertility, species or other unexpected environmental factors. Srisaikham and Lounglawan (2018) reported a similar reduction in CP of Crotalaria juncea when harvested at longer intervals, while the accumulation of cell walls and lignocellulose content markedly increased over greater intervals of time. Normally, the high lignified fiber obtained from the stem when the plants grow older produces a much higher total DM yield, but quality, which measured the $\mathrm{CP}$ portion of the leaves, decreased, which is consistent with some previous reports of nutritive values containing variable quantities of CP in sunnhemp at different cutting intervals and heights (Muir, 2002). With regard to the CP and $\mathrm{CF}$ yield and the current production results, the optimum cutting intervals and cutting height of sunnhemp for use as ruminant feed suggests that harvesting at intervals of 50 days is the most appropriate method. Nevertheless, cutting intervals at 30 days can have a marked effect on low fiber and high protein, a much lower yield than for intervals of 50 days, while the different cutting heights from 30 to $50 \mathrm{~cm}$ from ground level did not affect productivity. These results correspond to Srisaikham and Lounglawan (2018) who reported on sunnhemp and Suksombat and Buakeeree (2006) who reported on hedge lucerne (Desmanthus virgatus). However, the nutrient management depends on the type of fertilizer which influences the NPK levels and the spacing of seeds is also an important factor that influences the fiber yield of sunnhemp (Kavin et al., 2018). The nutritional content of $\mathrm{CP}$ is a common value measurement of protein, so it is often used to compare forages or to determine which quality of crop should be purchased. Protein levels are important for livestock because they are necessary for such ruminant animal products as meat and milk.

CP was a major nutrient in SM, accounting for $19.6 \%$, and similar results were observed in other research studies ( Srisaikham and Lounglawan, 2018), 
and these are also corroborated by Sherasia et al. (2015) who studied sunnhemp hay (Crotalaria juncea). Min et al. (2019) reported that sunnhemp forage samples of a period of $45 \mathrm{~d}$ were approximately $90 \% \mathrm{DM}, 17.8 \% \mathrm{CP}, 52 \%$ ADF, $53.1 \%$ NDF, $18 \%$ nonfibrous carbohydrate (NFC), 58. 9\% total digestibility nutritent (TDN), whereas some mineral concentrations were $0.85 \%$ calcium, $0.26 \%$ phosphate, $0.45 \%$ magnesium, $1.24 \%$ potassium and $0.16 \%$ sulphur. The values of UTRS in our study are within the normal range described for rice straw fermented with 5\% urea Badurdeen et al. (1994) who reported values of $7.7 \%$, but these are higher than Wora-anu (2000) who reported $6.9 \%$ in experiment. In contrast, the mean CP of UTRS was lower than that of Wanapat et al. (2000) who reported a value of $8.5 \%$. The chemical composition of these constituents may vary somewhat depending on rice varieties and various sources. Shen et al. (1998) conducted physical and chemical measurements of rice straw and they reported that weather, season, fertilizer usage and harvesting time were the main factors affecting the yield and components of rice straw. Shen et al. (1998) found that the season also affects the different chemical composition of rice straw, such as nitrogen, hemicellulose, cellulose and phosphorus content. In addition, the consistency of liquid urea used in the fermentation of the rice straw has a random effect on the chemical composition. Rice straw which has been treated with fermented with urea increased nitrogen levels from 35 to $171 \%$ (Shen et al., 1998).

The total DMI $(\mathrm{kg} / \mathrm{d})$ was affected by SM supplemented with UTRS at $75 \%(P<0.05)$ which resulted in less roughage of DMI at 0 and $25 \%$ in beef cattle feed diets. This might be due to a high percentage of DM in the supplemented SM diet that resulted from low moisture content when compared to UTRS and may also reduce palatability. The DM content should unaffected by the DMI of cows fed on diets which ranged from between 30 and 70\% DM (Holter and Urban, 1992). Moisture content has been reported to be negatively related to DMI, but this could be due to fermentation products rather than excess moisture (Allen, 2000) . NRC (2001) concludes that reports on the relationships between dietary DM content and DMI are conflicting and that, therefore, there is no optimum DM content of the diet for maximum DMI. In addition, this result might also be due to the fact that none of the experimental diets have been designed to be iso-nitrogenous or iso-caloric and the availability of feed in roughage ad libitum. However, the beef cattle fed diets based on a concentrated diet consumed less than the total DM of SM supplemented with UTRS at 0 and $25 \%$ compared to 50 and $75 \%(P<0.05)$ had less CF, NDF, ADF and ADL compared to SM supplemented with UTRS at 50 and $75 \%$, respectively. A linear decline in DMI was consequent upon an increased diet of NDF (Tafaj et al., 2007). Forage NDF diet is also a major factor affecting feed intake and rumen fill in high-producing animal ruminants (Noosen et al., 2020) 
which is consistent with the finding of Mertens (1994) who reported that the rumen fill was limited to DMI at high NDF concentrations in diets.

The final weight of beef cattle in this experiment was unaffected by the treatments due in part to the availability of roughage feed ad libitum during 60 days, but ADG is related to feed intake efficiency per day which is affected by the presence of the ratio of SM and UTRS supplements. LWC and ADG showed significantly different increases across diets which supplemented SM with UTRS at 0,25 and 50\%. An increment in ADG after supplementing SM with UTRS could possibly affect the intake of DM if it was similarly increased across the treatments. The increase in the growth rate is related to increased DMI (De Brito et al. , 2017), but not always in case of lamb fed on radish (Campbell et al., 2011), and thus a comparison with other studies should take into account the different numbers of animals for each treatment, the nutritive value of the forages, and should apply dissimilar experimental designs for feeding regimes. Higher live weight gains were also observed when mixtures of pastures (chicory, plantain, red and white clover) were included in the diet of lambs (Hutton et al., 2011), which is similar to Howes et al. (2015) who observed that an increase in both the efficiency of dietary protein and growth in lambs fed legumes which was compared to a more rapid rate of digestion than lambs fed on grass. In general, weight gain can be improved by supplementary feeding of lambs fed pasture or roughage (e.g. , dry pasture) Atti and Mahouachi (2009) and Turner et al. (2014). Nevertheless, the LWC and ADG decreased throughout from 75\% SM supplementation with UTRS ad libitum, which is consistent with a report on the intake of cattle fed on Brachiaria which increased linearly with decreasing legume content (Macedo et al., 2010). Few in vivo studies for tropical legumes in beef cattle research in Thailand have been found in the literature. Increasing of legumes proportion in the diet above $75 \%$ of DM appeared to have little effect on the intake of forage and an analysis did not indicate a significant deviation from a linear relationship (Macedo et al., 2010).

The treatments had no effect on the apparent nutrient digestibility of DM, $\mathrm{CP}, \mathrm{EE}, \mathrm{CF}, \mathrm{NDF}$ and ADF in the total digestive tract (Table 5) nor on rumen $\mathrm{pH}, \mathrm{NH}_{3}-\mathrm{N}$ and VFAs concentration at $0 \mathrm{~h}$ before and after post feeding (Table 6) $(P>0.05)$. The rumen $\mathrm{pH}$ level in all experimental groups was between 6.83 and 6.91, which is in the range of the normal rumen $\mathrm{pH}$ level of the ruminants between 5.5 - 7.0 (Dehority, 2003). To better understand the changes in rumen $\mathrm{pH}, \mathrm{NH}_{3}-\mathrm{N}$ and VFA concentrations after animals were fed on diets, an analysis was conducted of the breakdown and digestion of the ruminal microbes: the initial step showed the rumen $\mathrm{pH}$ was mostly low during the first 3 to $4 \mathrm{~h}$ after post feeding (Zimmer and Cordesse, 1996), and then gradually increased after fermentation by the microbes. Ruminal $\mathrm{NH}_{3}-\mathrm{N}$ concentration increased after $3 \mathrm{~h}$ with the increased fermentation process after feeding, when the products of 
fermentation, mainly VFAs and microbial protein, then became available to the host ruminants. $\mathrm{NH}_{3}-\mathrm{N}$ is an important source of nitrogen for use in microbial protein synthesis (Prihartini and Khotimah, 2011). Ruminal $\mathrm{NH}_{3}-\mathrm{N}$ concentration showed a tendency to decrease when SM was supplemented with UTRS up to $75 \%$. In this case, the reduction of DMI possibly resulted in cattle receiving lower $\mathrm{CP}$ content than those fed at 0 and $25 \%$. Moreover, the mean $\mathrm{NH}_{3}-\mathrm{N}$ concentration was in the range of $9.64-12.88 \mathrm{mg} \%$ which was close to the results of Wora-anu (2000) who reported that the highest ruminal $\mathrm{NH}_{3}-\mathrm{N}$ concentration in cattle and buffaloes was found in those animals fed a ratio of 40: 60 of urea-treated rice straw with extracted rice bran. In addition, those groups of cattle that were fed at low SM supplemented with UTRS received a higher proportion of UTRS and the ruminal $\mathrm{NH}_{3}-\mathrm{N}$ at $4 \mathrm{~h}$ after post feeding tended to be higher than those fed at 50 and $75 \%$. However, no differences in nutrient digestibility were detected. Thus SM supplemented with UTRS had no influence on ruminal concentrations of $\mathrm{pH}, \mathrm{NH}_{3}-\mathrm{N}$ and VFAs, due to the fact that the nutrient digestibility of all four treatments did not show any significant differences between the groups.

\section{CONCLUSION}

This study clearly showed that cutting intervals of 50 days for sunnhemp with a cutting height of between 30 and $50 \mathrm{~cm}$ above ground level should be recommended to Thai farmers so that they can choose a useful alternative protein source for feeding beef cattle. Based of less than $75 \%$ of SM supplemented with UTRS is reccommened for beef cattle diet which has no effects on DMI, LWC, ADG, nutrient digestibility, rumen-pH, $\mathrm{NH}_{3}-\mathrm{N}$ nor rumen VFA concentration.

\section{ACKNOWLEDGEMENTS}

The authors would like to express their gratitude to the National Research Council of Thailand, the Suranaree University of Technology Farm and the Institute of Research and Development at the School of Animal Technology and Innovation, Institute of Agricultural Technology, Suranaree University of Technology, Thailand and Associate Professor Dr. Wisitiporn Suksombat for his technical suggestions. 


\section{REFERENCES}

Allen, M.S. 2000. Effects of diet on short-term regulation of feed intake by lactating dairy cows. Journal of Dairy Science. 83(7): 1598-1624. https:// doi.org/10.3168/jds.S0022-0302(00)75030-2

AOAC. 1990. Official methods of analysis. 2. $15^{\text {th }}$ ed. Arlington, VA: AOAC. p. 1-1298.

Atti, N., and Mahouachi, M. 2009. Effects of feeding system and nitrogen source on lamb growth, meat characteristics, and fatty acid composition. Meat Science. 81(2): 344-348. https://doi.org/10.1016/j.meatsci. 2008.08.011

Badurdeen, A.L., Ibrahim, M.N.M., and Schire, J.B. 1994. Methods to improve utilization of rice straw. II. Effects of different levels of feeding on intake and digestibility of untreated and urea ammonia treated rice straw. AsianAustralasian Journal of Animal Sciences. 7(2): 165-169. https://doi.org/ 10.5713/ajas.1994.165

Campbell, A. W., Maclennan, G., Judson, H. G., Lindsay, S., Behrent, M. R., Mackie, A., and Kerslake, J.I. 2011. Brief communication: The effects of different forage types on lamb performance and meat quality. Proceedings of the New Zealand Society of Animal Production. 71: 208210.

Chantiratikul, A., Liang, J. B., and Jelan, Z.A. 2006. Yield and chemical composition of kenaf (Hibiscus cannabinus) at different stages of maturity. Malaysian Journal of Animal Science. 11: 26-31.

Chaudhury, J., Singh, D. P. , and Hazra, S. K. 1995. Sunnhemp (Crotalaria juncea, L) . Central Research Institute for Jute \& Allied Fiber ( ICAR) Barrackpore, Parganas (North) West Bengal, India. p. 1-37.

De Brito, F. G., Ponnampalam, N. E., and Hopkins, L. D. 2017. The effect of extensive feeding systems on growth rate, carcass traits, and meat quality of finishing lambs. Comprehensive Reviews in Food Science and Food Safety. 16: 23-38. https://doi.org/10.1111/1541-4337.12230

Dehority, B.A. 2003. Rumen microbiology. Nottingham: Nottingham University Press.

Fraser, J., McCartney, D., Najda, H., and Mir, Z. 2004. Yield potential and forage quality of annual forage legumes in South Alberta and Northeast Saskatchewan. Canadian Journal of Plant Science. 84(1): 143-155. https://doi.org/10.4141/P02-100

Habtamu, L.D. 2014. A critical review on feed value of coffee waste for livestock feeding. World Journal of Biology and Biological Sciences. 2(5): 072-086. 
Holter, J.B., and Urban, W.E. 1992. Water partitioning and intake prediction in dry and lactating Holstein cows. Journal of Dairy Science. 75(6): 14721479. https://doi.org/10.3168/jds.S0022-0302(92)77904-1

Howes, N.L., Bekhit, A.E.A., Burritt, D.J., and Campbell, A.W. 2015. Opportunities and implications of pasture-based lamb fattening to enhance the long-chain fatty acid composition in meat. Comprehensive Reviews in Food Science and Food Safety. 14(1): 22-36. https://doi.org/ 10.1111/1541-4337.12118

Hutton, P.G., Kenyon, P.R., Bedi, M.K., Kemp, P.D., Stafford, K.J., West, D.M., and Morris, S.T. 2011. A herb and legume sward mix increased ewe milk production and ewe and lamb live weight gain to weaning compared to a ryegrass dominant sward. Animal Feed Science and Technology. 164(1): 1-7. https://doi.org/10.1016/j.anifeedsci.2010. 11.014

Kavin, S., Subrahmaniyan, K., and Kumari Mannan, S. 2018. Optimization of plant geometry and NPK levels for seed and fibre yield maximization in Sunnhemp [Crotalaria juncea ( L. )] Genotypes. Madras Agricultural Journal. 105(4-6): 156-160. https://doi.org/10.29321/MAJ. 2018.000121

Lawal, M. O., Aderolu, A. Z., Adeyemi, B., and Aarode, O.O. 2013. Dietary effects of Sun-hemp (Crotalaria juncea Linn.) in the diet of African catfish, Clarias gariepinus juveniles. Journal of Life and Physical Science (Acta SATECH). 4(2): 108-118

Lee, M. A., Davis, A. P., Chagunda, M. G. G., and Manning, P. 2017. Forage quality declines with rising temperatures, with implications for livestock production and methane emissions. Biogeosciences. 14: 1403-1417. https://doi.org/10.5194/bg-14-1403-2017

Lounglawan, P., Srisaikham, S., and Noosen, P. 2016. Utilisation of Sunnhemp (Crotalaria juncea) as roughage source in beef cattle. Paper presented at: International Conference on The 17th Asian-Australasian Association of Animal Production Societies Animal Science Congress (Fukuoka, Japan: Asian-Australasian Association of Animal Production Societies).

Macedo, R., Ferreira, R.E., Rezende, C.P., Pereira, J.M., Cadisch, G., Rouws, J.R.C., Alves, B.J.R., Urquiaga, S., and Boddey, R.M. 2010. Forage intake and botanical composition of feed for cattle fed Brachiaria/legume mixtures. Scientia Agricola (Piracicaba, Braz.). 67(4): 384-392. https:// doi.org/10.1590/S0103-90162010000400002

Martens, S.D., Tiemann, T.T., Bindelle, J., Peters, M., and Lascano, C.E. 2012. Alternative plant protein sources for pigs and chickens in the tropics nutritional value and constraints: a review. Journal of Agriculture and Rural Development in the Tropics and Subtropics. 113(2): 101-123. 
Mertens, D.R. 1994. Regulation of forage intake. In: Fahey, Jr., G.C., editors. Forage quality, evaluation, and utilization, American Society of Agronomy. Madison. p. 450-493.

Meteorological Department, Ministry of Information and Communication Technology. 2015. Statistics of temperature at meteorology station, Nakhon Ratchasima province: 2003 - 2015. Retrieved from http://service. nso.go.th/nso/web/statseries/statseries $27 . h t m l$

Min, B.R., Gurung, N., Shange, R., and Solaiman, S. 2019. Potential role of rumen microbiota in altering average daily gain and feed efficiency in meat goats fed simple and mixed pastures using bacterial tag-encoded FLX amplicon pyrosequencing ${ }^{1}$. Journal of Animal Science. 97(8): 35233534. https://doi.org/10.1093/jas/skz193

Mkiwa, F.E.J., Sarwatt, S.V., Lwoga A.B., and Dzowela, B.H. 1990. Nutritive value of Crotalaria ochroleuca: I chemical composition and in vitro dry matter digestibility at different stages of growth. In: Dzowela, B.H., editor. Utilization of research results on forage and agricultural byproduct materials as animal feed resources in Africa. Proceedings of the First Joint Workshop Held in Lilongwe, Malawi, 5-9 December 1988. Addis Ababa, Ethiopia.

Muir, J.P. 2002. Effect of dairy compost application and plant maturity on forage kenaf cultivar fiber concentration and in sacco disappearance. Crop Science. 42(1): 248-254. https://doi.org/10.2135/cropsci2002.2480

Noosen, P., Lounglawana, P., Srisaikham, S., and Suksombat, W. 2020. Effect of linseed oil supplementation on production, composition and n-6/n-3 fatty acid ratio in cow's milk. Chiang Mai University Journal of Natural Sciences. 19(1): 17-33. https://doi.org/10.12982/CMUJNS.2020.0002

NRC. 2001. Nutrient requirements of dairy cattle. $7^{\text {th }}$ revised ed. Washington, DC: National Research Council, National Academy Press.

Prihartini, I., and Khotimah, K. 2011. Production of rumen probiotic base on lignocloritic bacteria and the application to dairy cows. Gamma. 7(1): 2731.

Sarkar, S.K., and Ghoroi, A.K. 2007. Sunnhemp as a green manure. International Journal of Agricultural Sciences. 3(1): 244-248.

Sarkar, S.K., Hazra, S.K., Sen, H.S., Karmakar, P.G., and Tripathi, M.K. 2015. Sunnhemp in India. ICAR-Central Research Institute for Jute and Allied Fibres (ICAR), Barrackpore, West Bengal

SAS, (Statistical Analysis System). 2001. SAS user' guide: Statistics. NC: SAS Institute.

Seyoum, B., Zinash, S., and Dereje, F. 2007. Chemical composition and nutritive values of Ethiopian Feeds. EIAR. Research Report 73. Addis Ababa, Ethiopia. 
Shen, H.Sh., Ni, D.B., and Sundstol, F. 1998. Studies on untreated and ureatreated rice straw from three cultivation seasons: 1 . Physical and chemical measurements in straw and straw fractions. Animal Feed Science and Technology. 73: 243-261.

Sherasia, P.L., Garg, M.R., Phondba, B.T., and Hossain, S.A. 2015. Estimation of metabolizable energy, net energy-lactation and total digestible nutrients of some ruminant feedstuffs using in vitro gas production technique. Indian Journal of Dairy Science. 68(4) : 370-375. https://doi.org/10.5146/ijds.v68i4.43379

Srisaikham, S., and Lounglawan, P. 2018. Effect of cutting age and cutting height on production and nutritive value of sunnhemp (Crotalaria juncea) harvest in Nakhon Ratchasima, Thailand. Acta Horticulturae. 1210: 2934. https://doi.org/10.17660/ActaHortic.2018.1210.4

Srisaikham, S., and Rupitak, Q. 2019. Effects of feeding Leguminosae on productive performance in meat goat. Unpublished manuscript.

Srisaikham, S., Aubonphap, S., Kunprasert, S., and Rupitak, Q. 2019. Study of cutting age on yield of forage legumes 3 types in Sakaeo province during dry season. Proceeding of the $2^{\text {nd }}$ International Conference on Tropical Animal Science and Production. Vol. 2 Integrated approach in advanced animal technology and innovation in the tropics. Nakhon Ratchasima: Suranaree University of Technology Press. p.49-52.

Steel, R.G.D., and Torries, J.H. 1980. Principles and procedures of statistics. A biometrical approach. $2^{\text {nd }}$ ed. New York: McGraw-Hill Book Co. p. 1688.

Suksombat, W., and Buakeeree, K. 2006. Effect of cutting interval and cutting height on yield and chemical composition of hedge lucerne (Desmanthus virgatus). Asian-Australasian Journal of Animal Sciences. 19( 1): 31-34 https://doi.org/10.5713/ajas.2006.31

Sumalu, K., Lounglawan, P., and Suksombat, W., 2012. Effect of cutting height and cutting age on production and nutritive value of sunnhemp (Crotalaria juncea) . Proceeding of the International Conference on Animal Production and Environment. Symposium conducted at the meeting of Can Tho University, Can Tho, Vietnam.

Tafaj, M., Zebeli, Q., Baes, C. H., Steingass, H., and Drochner, W. 2007. A meta-analysis examining effects of particle size of total mixed rations on intake, rumen digestion and milk production in high-yielding dairy cows in early lactation: Review. Animal Feed Science and Technology. 138: 137-161. https://doi.org/10.1016/j.anifeedsci.2007.06.020

Tripathi, M.K., Chaudhary, B., Bhandari H.R., and Harish, E.R. 2012. Effect of varieties, irrigation and nitrogen management on fibre yield of sunnhemp. Journal of Crop and Weed. 8(1): 84-85. 
Tripathi, M.K., Chaudhary, B., Sarkar, S.K., Singh, S.R., Bhandari, H.R., and Mahapatra, B.S. 2013. Performance of Sunnhemp (Crotalaria juncea L.) as a summer season (Pre-Monsoon) crop for fibre. Journal of Agricultural Science. 5(3): 236-242. https://doi.org/10.5539/jas.v5n3p236

Turner, K. E., Belesky, D. P., Cassida, K. A., and Zerby, H. N. 2014. Carcass merit and meat quality in Suffolk lambs, Katahdin lambs, and meat-goat kids finished on a grass-legume pasture with and without supplementation. Meat Science. 98(2): 211-219. https://doi.org/10.1016/ j.meatsci.2014.06.002

USDA. 1999. Sunn hemp: a cover crop for southern and tropical farming systems. USDA-NRCS, Soil Quality Institute, Agronomy Technical Note No. 10

Van Soest, P.J., Robertson, J.B., and Lewis, B.A. 1991. Methods for dietary fiber, neutral detergent fiber and non-starch polysaccharides in relation to animal production. Journal of Dairy Science. 74(10): 3583-3597. https:// doi.org/10.3168/jds.S0022-0302(91)78551-2

Wanapat, M., Chumpawadee, S., and Paengkoum, P. 2000. Utilization of ureatreated rice straw and whole sugar cane crop as roughage source for dairy cattle during the dry season. Asian-Australasian Journal of Animal Sciences. 13(4): 474-477. https://doi.org/10.5713/ajas.2000.474

Wanapat, M., and Rowlinson, P. 2007. Nutrition and feeding of swamp buffalo: feed resources and rumen approach. Italian Journal of Animal Science. 6(Suppl. 1): 67-73. https://doi.org/10.4081/ijas.2007.s2.67

Wanapat, M., Polyorach, S., Boonnop, K., Mapato, C., and Cherdthong, A. 2009. Effects of treating rice straw with urea or urea and calcium hydroxide upon intake, digestibility, rumen fermentation and milk yield of dairy cows. Livestock Science. 125(2-3): 238-243. https://doi.org/ 10.1016/j.livsci.2009.05.001

Wanapat, M., Pilajun, R., and Rowlinson, P. 2013.Effect of carbohydrate source and cotton seed meal level in the concentrate: IV. Feed intake, rumen fermentation and milk production in milking cows. Tropical Animal Health and Production. 45: 447-453. https://doi.org/10.1007/s11250-0120238-6

Wora-anu, S. 2000. A comparative study on roughage to concentrate ratio on ruminal microorganisms, fermentation process, end-products and voluntary feed intake in cattle and swamp buffaloes fed on urea-treated rice straw [master's thesis]. Khon kaen: Khon kaen University.

Zimmer, N., and Cordesse, R. 1996. Digestibility and ruminal digestion of nonnitrogenous compounds in adult sheep and goats: Effects of chestnut tannins. Animal Feed Science and Technology. 61(1-4): 259-273. https:// doi.org/10.1016/0377-8401(95)00940-X 